УДК 338.1

\title{
США ТА КАНАДА: ТЕНДЕНЦІї ЕКОНОМІЧНОГО РОЗВИТКУ І ПАРТНЕРСТВА
}

\section{USA AND CANADA: TRENDS IN ECONOMIC DEVELOPMENT AND PARTNERSHIP}

\author{
Манаєнко Ірина Миколаївна \\ кандидат економічних наук, доцент, \\ Національний технічний університет України \\ «Київський політехнічний інститут імені Ігоря Сікорського» \\ ORCID: https://orcid.org/0000-0002-3246-3603 \\ Бурий Єгор Петрович \\ студент, \\ Національний технічний університет України \\ «Київський політехнічний інститут імені Ігоря Сікорського» \\ ORCID: https://orcid.org/0000-0002-6638-2545 \\ Іванова Дар'я Андріївна \\ студентка, \\ Національний технічний університет України \\ «Київський політехнічний інститут імені Ігоря Сікорського» \\ ORCID: https://orcid.org/0000-0003-0839-3534
}

\author{
Manaienko Iryna, Buryi Yehor, Ivanova Daria \\ National Technical University of Ukraine \\ «lgor Sikorsky Kyiv Polytechnic Institute»
}

\begin{abstract}
Стаття присвячена висвітленню стану економіки двох найвпливовіших країн світу - США та Канади. За допомогою економічного аналізу авторами статті визначено цілий ряд факторів через що ці країни мають перевагу рештою світу. Поміж цих фрактов були: рівень залежності між економічним зростанням та взаємовідносинами даних країн; ступінь залученості країн Північної Америки до міжнародних інтеграційних процесів, обсяг експорту та імпорту, важливі події у розвитку країн. Крім цього, у статті показано динаміка основних макроекономічних показників (ВВП та детальну структуру обігу товарів). Вивчення даного матеріалу призначене для усіх охочих з метою подальшого розуміння колосального успіху розвинутих країн, як наслідок для формування стратегічних планів вітчизняної економіки. Більшість вчених та економістів впевнені, що в сучасній світовій економіці здатність країн залишатися конкурентоспроможними все більше покладається на здатність розробляти та комерціалізувати інноваційні технології. Тож наша місія - сприяти власним економічним інноваціям та промисловій конкурентоспроможності, просуваючи науку, стандарти та технології вимірювання таким чином, щоб підвищити економічну безпеку та покращити якість нашого життя.
\end{abstract}

Ключові слова: глобалізація, інвестиції, співпраця, інтеграційні об'єднання, торгівельний оборот, економічна політика.

Статья посвящена двум ведущим странам мира - США и Канаде. С помощью экономического анализа авторами был определён целый ряд фракторов, который привёл к успеху данные страны и дал им преимущества над остальными. К этим фракторам можно отнести: уровень зависимости экономического роста от взаимоотношений данных стран, уровень вовлеченности стран Северной Америки к международным интеграционным процессам, структура импорта и экспорта товаров, ключевые моменты в истории стран. Кроме того, в статье показана динамика основных макроэкономических показателей (Валовый внутренний продукт и детальная структура оборота товаров) данных стран. Изучения данного материала поможет всем желающим лучше понимать колоссальный успех развитых стран, а в следствие привёдет к умению фрормировать стратегические планы отечественной экономики.

Ключевые слова: глобализация, инвестиции, сотрудничество, интеграционные объединения, торговый оборот, экономическая политика. 
The relevance of the article is revealed through the rapid growth of the economy and the frequent change of its cycles. More specifically, this research aims to investigate the role of the two most powerful economies in the world the United States of America and Canada. Authors could identify a number of factors that led to the success of these countries and gave them advantages over the rest with the help of economic analysis. These factors are included: the level of dependence of economic growth on the relationship of these countries, the level of involvement of North American countries in international integration processes, the structure of imports and exports of goods. The history of the countries and its key points are described, besides history there is shown infographic with main events that became the precondition for the emergence of NAFTA and other global organizations. In addition, the article shows the dynamics of the main macroeconomic indicators (Gross Domestic Product and the detailed structure of the turnover of goods) of these countries. All this information is very important because it gives a more detailed picture of the life of countries and their success. The study of this material will help everyone to better understand the colossal success of developed countries, and as a result, it will lead to the ability to form strategic plans for the domestic economy. As you know there are 4 cycles of economic. During the expansion phase, the economy experiences relatively rapid growth, interest rates tend to be low, production increases, and inflationary pressures build. The peak of a cycle is reached when growth hits its maximum rate. Peak growth typically creates some imbalances in the economy that need to be corrected. This correction occurs through a period of contraction when growth slows, employment falls, and prices stagnate. The trough of the cycle is reached when the economy hits a low point and growth begins to recover. Global economic is in recession. Most scientists and economists are convinced that we can solve this problem and move to expansion using the ability of the countries to remain competitive relies increasingly on the ability to develop and commercialize innovative technologies. So our mission is to promote our own economic innovation and industrial competitiveness by advancing measurement science, standards and technology in ways that enhance economic security and improve our quality of life.

Keywords: globalization, investments, cooperation, integration associations, trade volume, economic policies.

Постановка проблеми. В умовах сучасної глобалізації та міжнародного поділу праці рівень економічного розвитку країни визначається ступенем ії̈ залученості у міжнародні інтеграційні процеси. Це пояснює характерність ланцюгових реакцій як позитивних, так і негативних. Спад чи зменшення темпів розвитку розвинутих країн через півроку призводить до серйозних криз у економічно менш розвинутих державах. При такому сценарію необхідно дослідити динаміку макроекономічних показників лідерів сучасної світової економіки. Вибір США і Канади обумовлений їхнім значним впливом на більшості континентах, провідною роллю у визначенні спектрів розвитку світового виробництва та характером залученості у світову торгівлю вцілому.

Аналіз останніх досліджень і публікацій. Враховуючи домінуюче положення країн у світовій економіці, доволі висока кількість вітчизняних та ще більша закордонних науковців розглядають економічні показники США та Канади, аби виділити ключові аспекти розвитку цих країн на конкретний період часу.

У інфрормаційному потоці можна виділити наступних авторів, чиї праці залишаються актуальними на даний момент: А. Кімберлі [8], Д. Воркман [5], Б. Гончар [2], Д. Артемчук [10]. Враховуючи той фракт, що обидві країни $€$ англомовними, то і більшість робіт написані відповідною мовою. Також варто зазначити, що переважна більшість статистичних даних була отримана з серверу Світового банку [9], домінуючу квоту в якому належить саме Спо- лученим Штатам, також статистичні дані взято із бази Департаменту національної безпеки США [6], онлайн платорорми Статиста [7].

Виділення невирішених раніше частин загальної проблеми. Не зважаючи на вищезазначені наукові праці, більша кількість 3 них окремо розглядають економічне стаановище досліджуваних країн, не проводячи їх компаративного аналізу. Набагато менша чисельність наукових праць, у яких порівнюються дані обох країн та аналізується їх партнерство у цілому. Цей факт обумовлює валивість та актуальність такого роду робіт.

Географрічна близькість та економічна розвиненість як США так і Канади обумовлює їх потужний вплив та велику кількість міжнародних питань, тому опускати їх співробітництво, аналізуючи вплив, означає значно зменшувати актуальність отриманих результатів.

Постановка завдання. Метою статті $\epsilon$ економічна діагностика макроекономічних показників США та Канади, як провідних економік світу з одного боку, а з іншого - як важливих суб'єктів НАФТА. Актуально також визначити ключові аспекти успіху відносин між США та Канадою. Для цього розглянемо основні макроекономічні показники цих країн. Шляхом аналізу отриманих даних варто виділити імовірні спектри розвитку цих економік, завдяки чому можна розробляти стратегічні плани на вітчизняному ринковому просторі.

Виклад основного матеріалу дослідження. На сьогоднішній день у світі все більш і більш набирає обертів глобалізація, 
тобто посилюються регіоналізації внутрішніх та зовнішніх міжнародних відносин, зростає взаємозалежність економік окремих країн, прискорюється обмін товарами, послугами, капіталами, інформацією. Для досягнення завдання цієї роботи критично важливо розглянути розвинені країни з взірцевими економіками, ринкові відносини яких, водночас, також займають важливу роль у світовій економіці. Саме тому далі пропонується розгляд становища США та Канади.

Дві країни тісно співпрацюють на різних рівнях - від місцевого та провінційного до фредерального. Канада та США також беруть активну участь у багатосторонніх групах, включаючи міжнародні зусилля щодо боротьби 3 фрінансуванням тероризму та відмиванням грошей. Дві країни належать до ряду однакових міжнародних організацій, включаючи OOH, HATO, COT, G7, G20, Організацію з безпеки та співробітництва в Європі, Організацію економічного співробітництва та розвитку.

Економічне положення США є лідируючим в областях виробництва нових технологій, електронної та комп'ютерної техніки, автомобілебудування та літакобудування тощо. Сполучені Штати Америки - це країна з найбільшим притоком іноземних інвестицій. Тим не менш останнім часом в економічній політиці США відбувається зміна орієнтованості від торгівлі до більш тісного господарського зв'язку з іншими країнами. Особливість цього процесу в тому, що поступово США за допомогою пропозиції своїх коштів у зарубіжних країнах створює контрольовані економіки.

Економіка Канади - одна з найвпливовіших економік капіталістичного типу на світовому рівні, чому сприяє близькість до США, високоосвічене та економічно активне населення та великі запаси природних ресурсів [7]. Провідними галузями промисловості за обсягами виробництва можна назвати насртову, газову, лісову і целюлозно-паперову промисловість, кольорова металургія, автомобільне будівництво.

США та Канада $є$ одними 3 тих країн, що лідирують за показником валового внутріш- нього продукти. У таблиці 1 представлені значення номінального ВВП США і Канади за останні 6 років. У ній яскраво видно, що на більшості обраного періоду прослідковувався зріст ВВП. Безумовно це можна пов'язати зі збільшенням риночної частки як США так і Канади та у багатьох країнах.

Показники ВВП, як для Канади так й для США на тлі пандемії коронавірусу зупинилися у рості та й знизилися 5,4\% та 2,35\% відповідно за підсумками 2020 року. Такі зміни спостерігаються в усіх різновидах ВВП. Також варто зазначити, що, порівнявши показник США і Канади, отримуємо залежність у 12 разів. Цей фракт є одним із підтвердженням того, що США насправді $є$ гегемоном у Західній півкулі.

Американці, що становлять менше 5 відсотків населення світу, виробляють і заробляють більше 20 відсотків від загального доходу в світі. Америка - найбільша в світі національна економіка і провідний світовий трейдер. Економіка Канади не займає таке високе положення, але також $є$ визначної у світі.

Зовнішні економічні відносини обумовлюються передусім саме міжнародною торгівлею. Лідером $з$ експорту безумовно залишається Китай, однак виробничі потужності Канади, а особливо США, підносять досліджувані країни до дванадцятої та другої сходинки відповідно [3]. Визначення економік країн таких, що можна назвати експортно орієнтованих деякою мірою обумовлює подальші плани розвитку виробничої сорери та програм збуту.

Провідну роль в економіці США належить промисловості, а саме металургії, машинобудуванню і приладобудуванню, сфрері електронного та електротехнічного, насртового, хімічного, автомобільного виробництва. Основу експортної стратегії США складають машини і обладнання (США $є$ джерелом приблизно $20 \%$ світового експорту наукоємної продукції). 3 приводу Канади, то основу експорту (60\%) складають вироби гірничодобувної промисловості, кольорової металургії, енергетики, лісової і целюлозно-паперової промисловості.

Динаміка зміни номінального ВВП у США та Канаді

Таблиця 1

\begin{tabular}{|c|c|c|c|c|c|c|}
\hline Країна & $\begin{array}{c}\text { Номінал. } \\
\text { ВВП } \\
\mathbf{2 0 1 5} \text { рік, } \\
\text { трлн. дол. }\end{array}$ & $\begin{array}{c}\text { Номінал. } \\
\text { ВВП } \\
\mathbf{2 0 1 6} \text { рік, } \\
\text { трлн. дол }\end{array}$ & $\begin{array}{c}\text { Номінал. } \\
\text { ВВП } \\
\mathbf{2 0 1 7} \text { рік, } \\
\text { трлн. дол }\end{array}$ & $\begin{array}{c}\text { Номінал. } \\
\text { ВВП } \\
\mathbf{2 0 1 8} \text { рік, } \\
\text { трлн. дол }\end{array}$ & $\begin{array}{c}\text { Номінал. } \\
\text { ВВП } \\
\mathbf{2 0 1 9} \text { рік, } \\
\text { трлн. дол }\end{array}$ & $\begin{array}{c}\text { Номінал. } \\
\text { ВВП } \\
\mathbf{2 0 2 0} \text { рік, } \\
\text { трлн. дол }\end{array}$ \\
\hline США & 18,22 & 18,71 & 19,51 & 20,58 & 21,43 & 20,93 \\
\hline Канада & 1,55 & 1,52 & 1,65 & 1,71 & 1,73 & 1,64 \\
\hline
\end{tabular}

Джерело: складено авторами на основі [3] 


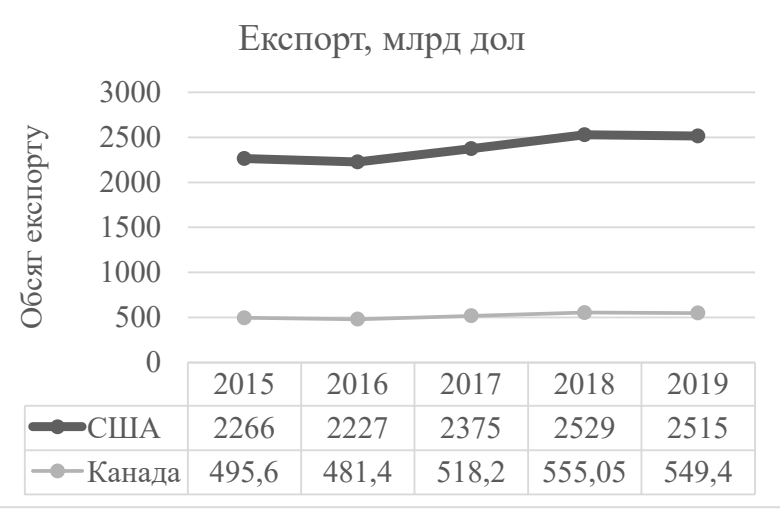

Рис. 1. Грошовий еквівалент експорту США та Канади, млн дол.

Джерело: побудовано авторами на основі [9]

Канада є потужним постачальником сировини та напівфрабрикатів на міжнародний ринок, експортуючи понад 80\% продукції видобувної промисловості [9]. Експорт країн у грошовому еквіваленті можна відслідити за допомогою рисунку 1.

2019-го року обсяг експорту у грошовому еквіваленті для США склав 2515 млрд доларів, а Канади - 549 млрд [3]. Одразу можна помітити, що показники Канади у 4,5 рази менші за США. Хоч рівень життя та трудові гарантії обох країн знаходяться на високому рівнях, виробничі потужності США врази випереджають канадські. Статус західного гегемона вже закріпився за Штатами, вони виробляють широкий спектр товарів, що користуються попитом по всьому світу і Канада просто не в змозі конкурувати з таким гігантом, отже виробляє інші товари та послуги, що не підпадають під інтереси США.

Схожа ситуація і 3 імпортними показниками. Як не парадоксально, однак перше місце за імпорт в США посідають машини та обладнання (у тому числі програмне забезпечення) далі - електричне обладнання, транспортні засоби, мінерали, паливо, насрта, фрармацевтична продукція, меблі, пластмаси, дорогоцінні метали та хімічні речовини [8]. Для

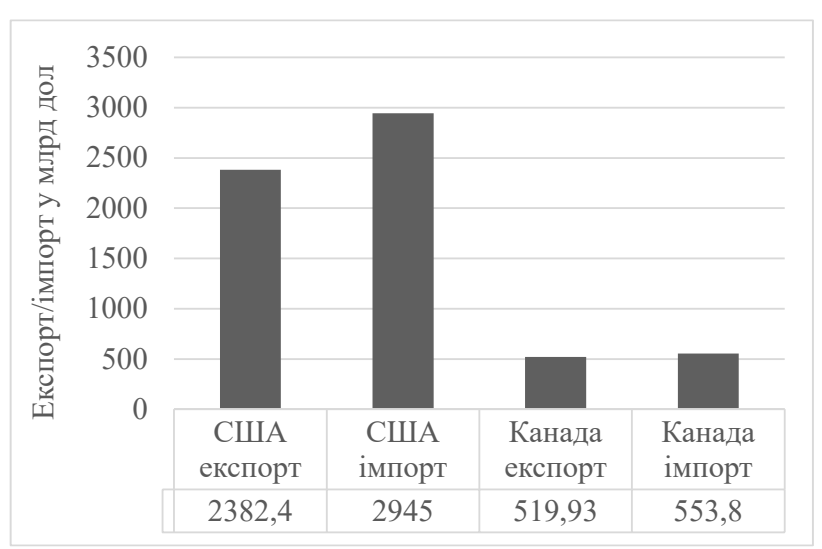

Рис. 2. Середні значення по експорту/імпорту США і Канади

Джерело: побудовано авторами на основі [9]

Канади список імпортованих товарів виглядає ідентично, за виключенням: важлива частка імпорту - вироби з заліза

Якщо порівняти значення обох показників, то можна зробити висновок, що в США імпорт значно випереджає експорт, у Канаді ці показники відносно рівні. Такий нетипічний характер відносин не заважає домінувати на світовому ринку США тому, що сам ринок продовольчих товарів Сполучених Штатів один з найбільших у світі, країна отримує податки, а прибуток не йде до резидентів однієї країни, а розподіляється між деякими провідними, якість продукції яких відповідає високим стандартам американців. Якщо взяти середні значення за 5 років обох показників для США та Канади, то результати можуть бути представлені у вигляді, як на рисунку 2. Таким чином можна порівняти обсяги торгівлі Канади та США.

На значення експорту та імпорту впливають також чисельність населення, отже варто розглянути ці показники, скореговані на душу населення. Врахувавши чисельність населення, можна якісніше уявити розподіл благ держави серед усіх громадян. Отримані результати представлені у таблиці 2 за 5 років.

Отже, як і варто було очікувати, значення обох показників для Канади перевищують

Експорт та імпорт на душу населення США та Канади, 1000 дол/люд

\begin{tabular}{|c|c|c|c|c|c|c|}
\hline & Країна & $\mathbf{2 0 1 5}$ & $\mathbf{2 0 1 6}$ & $\mathbf{2 0 1 7}$ & $\mathbf{2 0 1 8}$ & $\mathbf{2 0 1 9}$ \\
\hline \multirow{2}{*}{ Експорт } & США & 7,02 & 6,85 & 7,26 & 7,69 & 7,60 \\
\cline { 2 - 7 } & Канада & 13,73 & 13,17 & 13,98 & 14,77 & 14,46 \\
\hline \multirow{2}{*}{ Імпорт } & США & 8,65 & 8,43 & 8,96 & 9,54 & 9,44 \\
\cline { 2 - 7 } & Канада & 14,79 & 14,16 & 14,97 & 15,54 & 15,24 \\
\hline
\end{tabular}




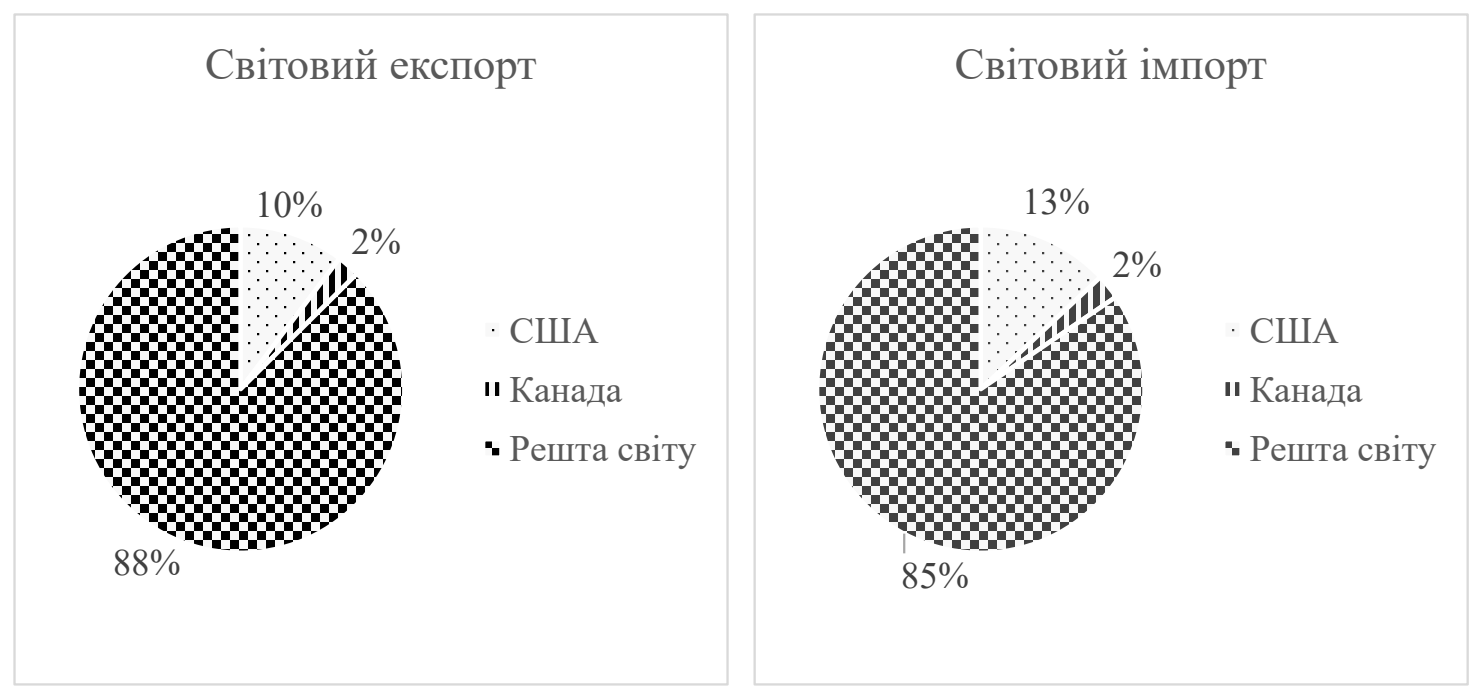

Рис. 3. Частка США і Канади у світовому експорті та імпорті [9]

відповідні показники Сполучених Штатів, що підтверджує думку про те, що менша кількість населення не означає повільніший економічний розвиток країни.

Для більш повного розкриття значення внеску США та Канади у світову торгівлю доречно буде надати інорормацію з частки цих країн у світовому експорті та імпорті. Відповідні дані наведені на рисунку 3.

Частка США та Канади складає приблизно 1/8 від усього експорту та імпорту товарів та послуг. 1/10 частина відноситься до США. Значна доля експорту надає змогу збувати великі масштаби товарів та розвивати виробництво національної економіки.

Найбільшими торговельними партнерами США $є$ безумовно Китай та Канада. Географрічна близькість Канади надає переваги у швидкому транспортуванню та збереженню якості товарів. Китай, як світовий лідер 3 виробництва найширшого спектру товарів, імпортує до країни товарів та послуг на загальну суму більшу за 438 млрд доларів, водночас США експортує до Китаю на 169 млрд, що створює десріцитні торгівельні відношення для Сполучених Штатів по відношенню до Китаю. Окрім згаданих країн, США співпрацює 3 Мексикою, Великобританією, Німеччиною, Францією, Південною Кореєю, Швейцарією та багатьма іншими країнами хоч і меншою мірою [6]. Торгові партнери Канади $€$ тими ж, що і партнери США: Китай, Мексика.

Продовжуючи питання зв'язків між країнами, розглянемо роль США та Канади в інтеграційних угрупуваннях. Для Північної Америки інтеграційні процеси обумовлені одним масштабним об'єднанням НАФТА (англ. North
American Free Trade Agreement - NAFTA). Вона поєднує усі три країни континенту США, Канада та Мексику - в один спільний ринок, у центрі якого знаходяться Сполучені Штати. Передумовами до створення НАФТА був ряд історичних моментів:

- 1947 р. Розроблено «План Еббота», передбачав стимулювання інвестиції США у провідні галузі Канади;

- 1959 р. Угода про спільне воєнне виробництво між США та Канадою;

- 1965 р. Двостороння угода про лібералізацію торгівлі продукцією автомобілебудування;

- 1988 р. Угода про вільну торгівлю між США та Канадою;

- 1994 р. Угода про північноамериканську зону вільної торгівлі (НАФТА) між США, Канадою та Мексикою;

- 2019 р. Підписання нової угоди USMCA $[1 ; 4]$.

Як видно, початково це була двостороння угода про співпрацю США та Канади, до якої згодом приєдналася Мексики і утворила сучасний вигляд угрупування. Сполучені Штати в результаті укладання цієї угоди отримали значні вигоди:

- в переважній більшості галузей були поступово зведені до мінімуму бар'єри проти іноземних виробників 3 країн-партнерів по НАФТА, що дозволяло закупляти у них багато товарів дешевше, ніж в самих США;

- перед американськими компаніями відкрилися більш широкі можливості доступу на ринки країн-сусідів, що розширювало ринок збуту [4].

Зацікавленість Канади в членстві в НАФТА пов'язана 3 можливістю не тільки збере- 
ження переваг CUSFTA (канадсько-американської співпраці), але і модифікації деяких її положень, а також забезпечення надійного доступу своїх товарів на мексиканський ринок, а в майбутньому на швидко зростаючі ринки латиноамериканських країн.

Спільний для трьох сторін інтерес полягає в тому, об'єднаними зусиллями протистояти посиленню впливу західноєвропейського інтеграційного об'єднання в особі ЄС [10]. НАФТА має протистояти також могутньому економічному піднесенню Азійсько-Тихоокеанського регіону, який, на думку багатьох дослідників, досить серйозно претендує на роль світового центру в XXI ст. США дійшли висновку, що їхньої одноосібної присутності в цьому регіоні вже недостатньо, щоб адекватно реагувати на можливі зміни у розстановці світових економічних сил або, принаймні, підтримувати рівновагу між ними. Кожна із трьох країн учасниць має свої економічні інтереси в НАФТА і, звісно, кожна з них плекає надію за допомогою вільної торгівлі реалізувати ці інтереси.

Можна зробити висновок, що інтеграційні процеси США та Канади більшою мірою розкриваються через співпрацю у форматі НАФТА. Через посилення впливу азійських економік на світові процеси, такого роду угруповування постають перед серйозним конкурентом. Можна впевнено сказати, що у майбутньому нова угода про співпрацю USMCA буде спрямована на економічне протистояння з інтеграційними угрупованнями.

Сполучені Штати Америки $€$ активним учасником міжнародного життя, у тому числі через міжнародні організації. США прагнуть використовувати і використовують міжнародні організації як інструменти поширення свого впливу, але, стикаючись 3 активною протидією, у багатьох випадках не відчувають себе пов'язаними позиціями інших членів міжнародного співтовариства. 3 часу закінчення холодної війни США використовують наступну модель міжнародної поведінки: віддаючи перевагу багатостороннім діям, в разі необхідності США залишають за собою право діяти в односторонньому порядку, створюючи видимість широкого міжнародного консенсусу за рахунок використання тимчасових союзів і коаліцій (ad-hoc coalitions) замість усталених міжнародних організацій.

США стояли біля витоків створення $\mathrm{OOH}, \epsilon$ постійним членом Ради Безпеки, а також членом спеціалізованих установ ООН, таких як МВФ, МБРР, МАГАТЕ, ЮНЕСКО, ВООЗ, МОП, BOІB, IKAO, ВМО, ВПС, ФАО та ін. США беруть участь і в таких організаціях як: Азіатський банк розвитку (нерегіональних член), Африканський банк розвитку (нерегіональних член), ЄБРР, ОБСЄ та ін. Головним інструментом військово-політичного впливу США $є$ НАТО.

Традиційно значною $€$ активність США в Західній півкулі. США відіграють провідну роль в ОАД, що займається питаннями політичного, економічного і гуманітарного співробітництва в Західній півкулі. Найважливішим напрямком латиноамериканської політики США, що просуваються в тому числі і через ОАД, $€$ розвиток економічної інтеграції в Західній півкулі. США відіграють провідну роль в двох субрегіональних інтеграційних об'єднаннях - Північноамериканську зону вільної торгівлі (НАФТА) і Центрально-американської зони вільної торгівлі (ДРЦАФТА), а також має двосторонні угоди про вільну торгівлю з Чилі і Перу [2].

Велика увага Канада приділяє своїм сусідам по північноамериканському і Американському континентах - перш за все Мексиці, яка бере участь з 1994 року поряд з США і Канадою в НАФТА [4], а також Чилі (з яким у Канади $є$ двостороння угода про вільну торгівлю), країнам басейну Карибського моря, 3 більшістю з яких у Канади історично склалися особливі відносини. Канада на відміну від США підтримує дипломатичні відносини і має чималі економічні інтереси на Кубі. Найбільш складні відносини з Бразилією, з якої Канада має ряд торгово-економічних розбіжностей, а також змагається за регіональний вплив в Карибському регіоні.

На початку XXI століття процес танення арктичного льодового покриву породив надії, що район, де знаходяться і північні території Канади, може в перспективі стати зоною активної видобутку природних ресурсів (в першу чергу вуглеводнів). У зв'язку з цим на передній план вийшла давня територіальна суперечка між Канадою і Данією про безлюдний острів Ханс, що знаходиться між територією Гренландії (Данія) і північним канадським островом Елсмір [5].

Висновки з проведеного дослідження. Розглянувши основні макроекономічні показники США та Канади ще раз пересвідчились, що економіки цих країн поступово зростають. Як результат, країни стаюсть все більш привабливими для інвесторів 3 усього світу та кваліфікованих кадрів, які щороку мігрують до Получених Штатів та Канади. Водночас ці країни $€$ взаємоінвесторами на засадах партнерства, солідар- 
ності та гармонізації їх політик. Розвиток та сучасний стан взаємовідносин цих країн мають зразковий характер та підлягають обов'язковому аналізу для розробки стратегічних планів з налагодження ефективних економічних зв'язків країн-сусідів. Перспективними питаннями, які можна надалі розвивати, є взаємовідносини окремих регіонів двох країн, геограсрічно близьких або ж у плані економічної спорідненості.

\section{СПИСОК ВИКОРИСТАНИХ ДЖЕРЕЛ:}

1. Дергачова В.В., Кузнєцова К.О., Манаєнко І.М. Міжнародні економічні відносини. Київ : КПІ ім. Ігоря Сікорського, 2019.

2. Гончар Б.М. США і ООН: деякі проблеми взаємодій. Київ : Наукова періодика, 2011.

3. Договір між Сполученими Штатами Америки, Сполученими Штатами Мексики та Канадою про торгівельне співробітництво. URL: https://ustr.gov/trade-agreements/free-trade-agreements/united-states-mexicocanada-agreement/agreement-between

4. Канадо-датські відносини. URL: https://www.international.gc.ca/country-pays/denmark-danemark/relations. aspx?lang=eng

5. Вуркман Даніель. Найбільші торгівельні партнери Канади. Торонто : Світовий експорт, 2020.

6. Іміграційна статистика. Міністерство національної безпеки США. 2020. URL: https://www.dhs.gov/ immigration-statistics

7. Іміграція до Канади: статистика та фракти. Cтатиста. 2021. URL: https://www.statista.com/

8. Кімберлі А., Бойл М.Дж. Статистика та компоненти експорту та імпорт США. Вашингтон : Баланс, 2020.

9. Світовий банк. URL: https://www.worldbank.org/

10.Артемчук Д.В., Конопка Н.О. Співробітництво США та Канади в сфрері безпеки і оборони на сучасному етапі. Наукові записки студентів та аспірантів. Серія «Міжнародні відносини». 2020. № 5. С. $278-287$. URL: https://eprints.oa.edu.ua/8291/1/32.pdf

\section{REFERENCES:}

1. Derhachova, V. V., Kuznietsova, K. O., \& Manaienko, I. M. (2019). Mizhnarodni ekonomichni vidnosyny [International Economic Relations]. Kyiv: KPI im. Ihoria Sikorskoho. (in Ukrainian)

2. Honchar, B. M. (2011). SShA i OON: deiaki problemy vzaiemodii [US and UN: some problems of interaction]. Kyiv: Naukova periodyka. (in Ukrainian)

3. Dohovir mizh Spoluchenymy Shtatamy Ameryky, Spoluchenymy Shtatamy Meksyky ta Kanadoiu pro torhivelne spivrobitnytstvo [Agreement between the United States of America, the United Mexican States, and Canada]. Retrieved from: https://ustr.gov/trade-agreements/free-trade-agreements/united-states-mexico-canada-agreement/ agreement-between

4. Kanado-datski vidnosyny [Canada-Denmark relations]. Retrieved from: https://www.international.gc.ca/ country-pays/denmark-danemark/relations.aspx?lang=eng

5. Vurkman, Daniel (2020). Naibilshi torhivelni partnery Kanady [Canada's Top Trading Partners]. Toronto: Svitovyi eksport.

6. Imihratsiina statystyka [Immigration Data and Statistics] (2020). Ministerstvo natsionalnoi bezpeky SShA. Retrieved from: https://www.dhs.gov/immigration-statistics

7. Imihratsiia do Kanady: statystyka ta fakty [Immigration in Canada: Statistics \& facts] (2021). Statysta. Retrieved from: https://www.statista.com/

8. Kimberli, A., Boil, M. J. (2020). Statystyka ta komponenty eksportu ta import SShA [US Imports and Exports with Components and Statistics]. Washington: Balans.

9. Svitovyi bank [The World Bank]. Retrieved from: https://www.worldbank.org/

10. Artemchuk D. V., Konopka N. O. (2020). Spivrobitnytstvo SShA ta Kanady v sferi bezpeky i oborony na suchasnomu etapi [Cooperation between the United States and Canada in the field of security and defense at the present stage]. Naukovi zapysky studentiv ta aspirantiv. Seriia «Mizhnarodni vidnosyny», (5), 278-287. Retrieved from: https://eprints.oa.edu.ua/8291/1/32.pdf (in Ukrainian) 